Key Words:

Mixing, Tank

$50 \mathrm{H}$, Sludge

Retention:

Permanent

\title{
ASSESSMENT OF THE ABILITY OF STANDARD SLURRY PUMPS TO MIX SOLIDS WITH LIQUID IN TANK 50H
}

Michael R. Poirier

November 11, 2011

Savannah River National Laboratory

Savannah River Nuclear Solutions

Aiken, SC 29808

Prepared for the U.S. Department of Energy Under

Contract Number DE-AC09-08SR22470

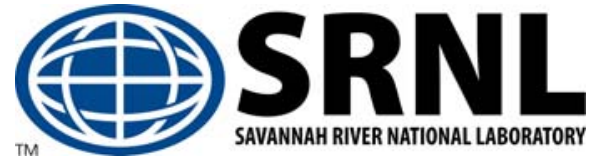




\section{DISCLAIMER}

This work was prepared under an agreement with and funded by the U.S. Government. Neither the U. S. Government or its employees, nor any of its contractors, subcontractors or their employees, makes any express or implied:

1. warranty or assumes any legal liability for the accuracy, completeness, or for the use or results of such use of any information, product, or process disclosed; or

2. representation that such use or results of such use would not infringe privately owned rights; or

3. endorsement or recommendation of any specifically identified commercial product, process, or service.

Any views and opinions of authors expressed in this work do not necessarily state or reflect those of the United States Government, or its contractors, or subcontractors.

Printed in the United States of America

Prepared for

U.S. Department of Energy 


\section{REVIEWS AND APPROVALS}

\section{Authors}

M. R. Poirier, SRNL, Advanced Characterization \& Processing

Date

\section{Design Check}

D. J. Adamson, SRNL, Engineering Development Laboratory

Date

Management

F. M. Pennebaker, Manager, SRNL, Advanced Characterization \& Processing $\quad$ Date

S. L. Marra, Manager, SRNL, E\&CPT Research Programs

Date

\section{Customer}

D. J. Martin, Manager, SRR, Tank Farm Process Engineering

Date

- ii - 


\section{TABLE OF CONTENTS}

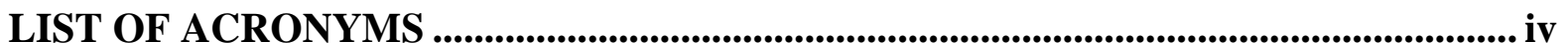

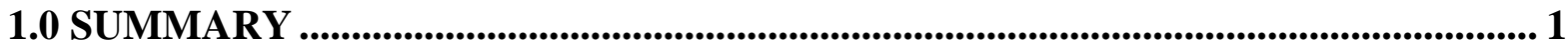

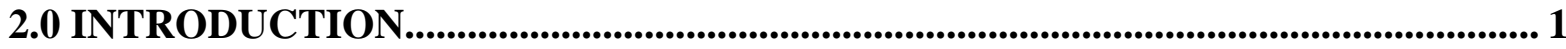

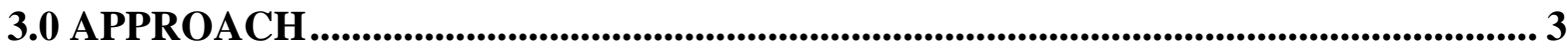

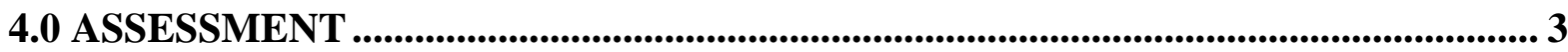

4.1 CFD ANALYSIS........................................................................................................ 3

4.2 SCIX MIXING TESTS ………........................................................................................... 4

4.3 REVIEW OF TANK 50H OPERATING EXPERIENCE ............................................ 7

4.3.1 Cleaning Radius Approach ........................................................................... 7

4.3.2 Critical Shear Stress Approach ............................................................................... 8

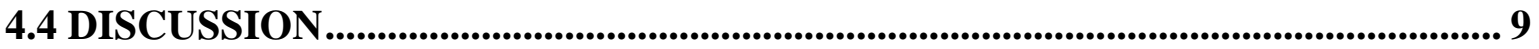

5.0 CONCLUSIONS ................................................................................................................ 10

6.0 REFERENCES.............................................................................................................. 10 


\section{LIST OF ACRONYMS}

$\begin{array}{ll}\text { ARP } & \text { Actinide Removal Process } \\ \text { CFD } & \text { Computational Fluid Dynamics } \\ \text { D } & \text { Pump Nozzle Inside Diameter } \\ \text { DSS-HT } & \text { Decontaminated Salt Solution Hold Tank } \\ \text { ETP } & \text { Effluent Treatment Project } \\ \text { ISDP } & \text { Integrated Salt Disposition Project } \\ \text { LWO } & \text { Liquid Waste Operations } \\ \text { MCU } & \text { Modular Caustic Side Solvent Extraction Unit } \\ \text { r } & \text { Height above centerline of pump discharge nozzle } \\ \text { rpm } & \text { Revolutions per minute } \\ \text { SDIP } & \text { Salt Disposition Integration Project } \\ \text { SPF } & \text { Saltstone Production Facility } \\ \text { SRNL } & \text { Savannah River National Laboratory } \\ \text { SRS } & \text { Savannah River Site } \\ \text { TTP } & \text { Telescoping transfer pump } \\ & \\ \mathrm{U}_{0} & \text { Pump Nozzle Discharge Average Velocity } \\ \text { t } & \text { Mixing Time To Reach 95\% of Equilibrium Value } \\ \text { T } & \text { Tank Inside Diameter } \\ v & \text { Fluid Velocity } \\ x & \text { Distance From Pump Discharge Nozzle }\end{array}$




\subsection{SUMMARY}

Tank $50 \mathrm{H}$ is the feed tank for the Saltstone Production Facility (SPF). In the summer of 2011, Tank $50 \mathrm{H}$ contained two standard slurry pumps and two quad volute slurry pumps. Current requirements for mixing operation is to run three pumps for one hour prior to initiating a feed transfer to SPF. Savannah River Site (SRS) Liquid Waste moved both of the Quad Volute pumps from Tank $50 \mathrm{H}$ to Tank $51 \mathrm{H}$ to replace pumps in Tank $51 \mathrm{H}$ that were failing. In addition, one of the standard pumps in Tank $50 \mathrm{H}$ exhibits high seal leakage and vibration. SRS Liquid Waste requested Savannah River National Laboratory (SRNL) to conduct a study to evaluate the feasibility of mixing the contents of Tank $50 \mathrm{H}$ with one to three standard slurry pumps.

To determine the pump requirements to mix solids with liquids in Tank 50H, the author reviewed the pilot-scale blending work performed for the Small Column Ion Exchange Process (SCIX), SRNL computational fluid dynamics (CFD) modeling, Tank $50 \mathrm{H}$ operating experience, and the technical literature, and applied the results to Tank $50 \mathrm{H}$ to determine the number, size, and operating parameters of pumps needed to mix the solid particles with the liquid in Tank $50 \mathrm{H}$. The analysis determined pump requirements to suspend the solids with no "dead zones", but did not determine the pump requirements to produce a homogeneous suspension. In addition, the analysis determined the pump requirements to prevent the accumulation of a large amount of solid particles under the telescoping transfer pump.

The conclusions from this analysis follow.

- The analysis shows that three Quad Volute pumps should be able to suspend the solid particles expected ( $\sim 0.6 \mathrm{~g} / \mathrm{L}$ insoluble solids, $\sim 5$ micron) in Tank $50 \mathrm{H}$.

- Three standard slurry pumps may not be able to suspend the solid particles in Tank 50H.

- The ability of two Quad Volute pumps to fully suspend all of the solid particles in Tank $50 \mathrm{H}$ is marginal.

- One standard slurry pump should be able to achieve a cleaning radius larger than 43.5 feet, which will prevent large amounts of solid particles from settling under the telescoping transfer pump (TTP). The report recommends a pump operating approach to maximize the achieved cleaning radius.

\subsection{INTRODUCTION}

Tank $50 \mathrm{H}$ is the feed tank for the Saltstone Production Facility. In the first quarter of the 2011 calendar year, Tank $50 \mathrm{H}$ accepted transfers of approximately $15 \mathrm{kgal}$ from the Effluent Treatment Project (ETP), approximately $15 \mathrm{kgal}$ from Tank 710 - the H-Canyon General Purpose Evaporator, approximately 73 kgal from the H-Canyon Super Kukla campaign, approximately 285 kgal from the Actinide Removal Process / Modular Caustic Side Solvent Extraction Unit (ARP/MCU) Decontaminated Salt Solution Hold Tank (DSS-HT), and approximately $21 \mathrm{kgal}$ from other sources. The DSS from ARP/MCU could contain as much as $50 \mathrm{mg} / \mathrm{L}$ of Isopar $\mathrm{L}^{\circledR}$. 1,2,3 The Isopar $\mathrm{L}^{\circledR}$ size is expected to be less than 20 microns. ${ }^{4,5}$ The entrained solids concentration is expected to be minimal $(\sim 0.6 \mathrm{~g} / \mathrm{L})$ and the particle size is on the order of 5 micron. ${ }^{6}$ 
In the summer of 2011, Tank 50H contained two standard slurry pumps and two Quad Volute slurry pumps. Current requirements and mixing operation is to run three pumps for one hour prior to initiating a feed transfer to SPF. ${ }^{7}$ Tank $51 \mathrm{H}$ contained four Quad Volute slurry pumps located in risers B1, B4, G, and H. During recent sludge batch washing, the pump in riser G experienced operational problems. In addition, the pump in riser B4 has experienced excessive bearing water leakage. Since Tank $51 \mathrm{H}$ is a sludge tank and Tank $50 \mathrm{H}$ is a salt tank, Tank $51 \mathrm{H}$ needs higher horsepower pumps than Tank 50H. SRS Liquid Waste moved both of the Quad Volute pumps from Tank $50 \mathrm{H}$ to Tank $51 \mathrm{H}$ to replace pumps in Tank $51 \mathrm{H}$ that were failing. In addition, one of the standard pumps in Tank $50 \mathrm{H}$ exhibits high seal leakage and vibration. This pump may become unusable in the near future.

SRS Liquid Waste requested Savannah River National Laboratory (SRNL) to conduct various literature studies to evaluate the feasibility of mixing the contents of Tank $50 \mathrm{H}$ with one to three standard slurry pumps. ${ }^{8}$

The objective provided by SRS Liquid Waste Operations (LWO) ${ }^{9}$ is to determine the required number, type, and operating parameters of the pump(s) needed to mix the contents of Tank $50 \mathrm{H}$ prior to transferring them to Saltstone for the various scenarios listed below:

1. Determine whether a single standard slurry pump is sufficient to mix the supernate in Tank $50 \mathrm{H}$ to a homogenous consistency. This work was based on previous SRNL studies and reports, the technical literature, and mixing calculations.

2. Determine the adequacy of one to three standard pumps being able to achieve a homogenous mixture of supernate and Isopar $\mathrm{L}^{\circledR}$. The bounding case will be the receipt of decontaminated salt solution from MCU to a tank at a maximum liquid level of 363 inches. MCU decontaminated salt solution transfer volume is 5500 gallons with volumes as high as 6,100 gallons reported. [If Tank $50 \mathrm{H}$ contains 363 inches of liquid $\left(1,274,000\right.$ gallons) with no Isopar $\mathrm{L}^{\circledR}$, and the MCU DSS transfers 6,100 gallons of DSS with $10 \mathrm{mg} / \mathrm{L}$ of Isopar $\mathrm{L}^{\circledR}$, the bulk Isopar $\mathrm{L}^{\circledR}$ concentration will be $0.05 \mathrm{mg} / \mathrm{L}$. If Tank $50 \mathrm{H}$ contains 285,000 gallons of DSS and 1,274,000 gallons of liquid, the bulk Isopar $\mathrm{L}^{\circledR}$ concentration would be $2.2 \mathrm{mg} / \mathrm{L}$.]

3. Assess whether one to three standard slurry pumps can establish a homogenous mixture of supernate, Isopar $\mathrm{L}^{\circledR}$, and solids at the transfer pump suction.

If one pump is not adequate, assess whether operation of a single standard pump can move the settled solids outside the transfer pump's zone of influence, i.e., show the solids won't reach the pump during simultaneous MCU addition and transfer to Saltstone.

4. If necessary, evaluate the feasibility of blending supernate, Isopar $L^{\circledR}$, and solid particles with quad-volute pumps.

In this document, SRNL will address scenarios 3 and 4 . Scenarios 1 and 2 were addressed in a previous report. $^{10}$ 


\subsection{APPROACH}

To determine the pump requirements to mix solids with liquids in Tank $50 \mathrm{H}$, the author reviewed the pilot-scale blending work performed for the Small Column Ion Exchange Process (SCIX) ${ }^{11}$, SRNL computational fluid dynamics (CFD) modeling ${ }^{15}$, Tank $50 \mathrm{H}$ operating experience, and the technical literature, and applied the results to Tank $50 \mathrm{H}$ to determine the number, size, and operating parameters of pumps needed to mix the solids with the liquid in Tank $50 \mathrm{H}$.

\subsection{ASSESSMENT}

Table 1 shows specific dimensional and performance aspects of the various mixer pumps deployed in the SRS Tank Farm. Figure 1 shows the Tank 50H riser locations.

Table 1. Dimensional and Performance aspects of Mixer Pumps in Tank 50H ${ }^{12,13,14}$

\begin{tabular}{|c|c|c|c|c|c|}
\hline \multirow{2}{*}{ Mixer } & \multicolumn{2}{|c|}{ Nozzle } & \multicolumn{3}{c|}{ At Maximum RPM } \\
\cline { 2 - 6 } & $\underline{\text { Number }}$ & $\underline{\mathrm{D}(\mathrm{in})}$ & $\underline{\underline{\mathrm{U}}_{0}(\mathrm{ft} / \mathrm{s})}$ & $\underline{\underline{\mathrm{U}}_{0}} \underline{\underline{\mathrm{D}}\left(\mathrm{ft}^{2} / \mathrm{s}\right)}$ & $\underline{\underline{\text { Power }}(\mathrm{HP})}$ \\
\hline Standard Slurry Pump & 2 & 1.5 & 109 & 13.6 & 70 \\
\hline Quad Volute Slurry Pump & 2 & 3.62 & 72 & 21.7 & 118 \\
\hline Submersible Mixer Pump & 2 & 4.4 & 79 & 29.0 & 230 \\
\hline
\end{tabular}

\subsection{CFD ANALYSIS}

The Scientific Engineering Computation group of SRNL performed Computational Fluid Dynamics (CFD) Modeling of jet mixing in Tank 50H with different slurry pump configurations. ${ }^{15}$ The model included the center column, the pump columns, and the pump housing, but it did not include the cooling coils. The pump(s) rotated at 1/5 rpm. The tank volume for the calculations was 1,000,000 gallons. The work determined that a fluid velocity of $0.23 \mathrm{ft} / \mathrm{s}$ was the minimum velocity required to pick up 10 micron sludge particles. The modeling assumed the sludge had no yield stress.

The calculations showed that three standard slurry pumps provided the energy needed to suspend the sludge and produce acceptable mixing, and that two standard slurry pumps were marginal. However, the calculations did not include the cooling coils and assumed that the sludge did not have a yield stress. The absence of cooling coils would lead to higher fluid velocities and more effective mixing. SRNL pilot-scale testing showed the presence of cooling coils increased the blending time by approximately $90 \% .{ }^{16}$ The lack of a yield stress would allow the sludge to be suspended at a lower pump discharge velocity. Because of the lack of cooling coils and the absence of a sludge yield stress, one should not conclude that three standard slurry pumps will mix and suspend the sludge in Tank $50 \mathrm{H}$ based on the CFD calculations. The CFD model should be used with experimental data to determine whether standard slurry pumps can suspend the solid particles in Tank 50H 


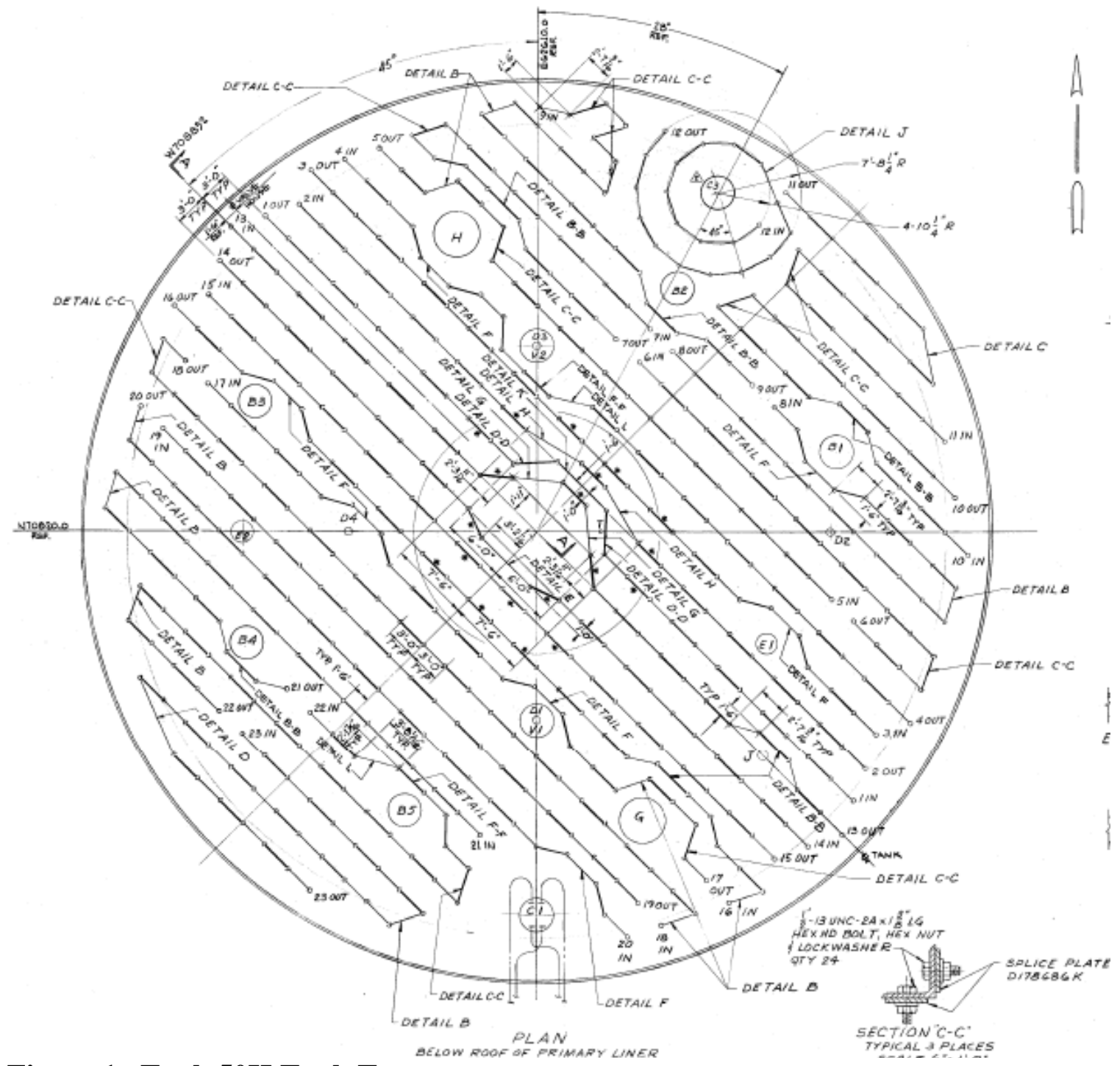

Figure 1. Tank 50H Tank Top

In 2003, when Tank $50 \mathrm{H}$ was mixed with two standard slurry pumps, large mounds (dead zones) were observed in the tank. ${ }^{19}$

\subsection{SCIX MIXING TESTS}

SRNL performed pilot-scale mixing tests to determine the pump requirements to suspend MST particles in a SRS Type IIIA waste tank with cooling coils (i.e., Tank 41H). ${ }^{11}$ Tank $50 \mathrm{H}$ is also a Type IIIA waste tank with cooling coils, and the coil designs of the two tanks are very similar. The tank (see Figure 2) was a 1/10.85 linear scaled model of Tank 41H. Scaled models of standard slurry pumps, Quad Volute slurry pumps, and Submersible Mixer Pumps (SMPs) were fabricated. 
As part of the testing, SRNL performed a scaling analysis to be able to apply the results to the SRS Tank Farm. ${ }^{17}$ The scaling analysis determined that to match the suspension of solid particles at the tank bottom, the pump nozzle discharge velocity in the full-scale tank would be $30 \%$ larger than the pump nozzle discharge velocity in the pilot-scale tank.

The scaling analysis determined that the cooling coils cause less reduction in fluid velocity at full-scale than at pilot-scale. ${ }^{17}$ That document estimated the impact at $29-45 \%$. Computational Fluid Dynamics (CFD) analysis of mixing in Tank 50H for the SDIP determined the cooling coils increased the mixing time by $2 \mathrm{X}$ at pilot-scale and $1.5 \mathrm{X}$ at full-scale. ${ }^{18}$ Therefore, the “effective $\mathrm{U}_{0} \mathrm{D}$ ” would need to increase by $2 \mathrm{X}$ at pilot-scale and $1.5 \mathrm{X}$ at full-scale to achieve the same fluid blending or solid suspension. The equivalent $\mathrm{U}_{0} \mathrm{D}$ would be $33 \%$ larger in the pilotscale tank than in the full-scale tank.

To account for scale up of the pilot-scale test results, the required nozzle discharge velocity measured in the pilot-scale should be multiplied by 1.3 to determine the required nozzle discharge velocity at full-scale. This velocity should be divided by 1.33 to account for the reduced impact of cooling coils at full-scale.

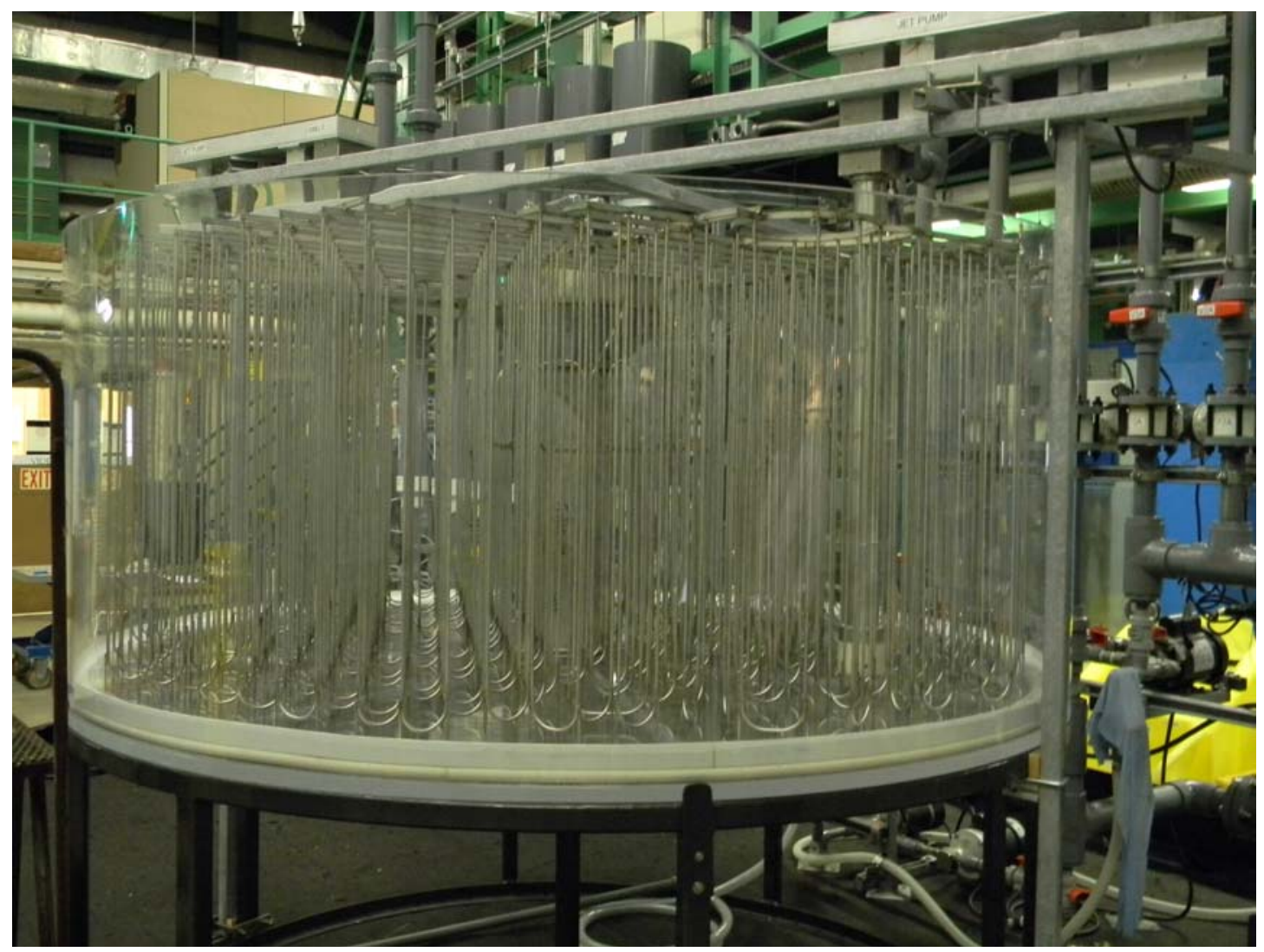

Figure 2. Pilot-Scale SRS Waste Tank

Table 2 shows the pump parameters needed to suspend MST particles in a pilot-scale waste tank and in a Type IIIA waste tank with cooling coils after settling overnight. The table shows the number of pumps tested, the measured $\mathrm{U}_{0} \mathrm{D}$ needed to suspend the solids in the pilot-scale tank, the calculated $\mathrm{U}_{0} \mathrm{D}$ needed to suspend the solids in the full-scale tank, the calculated $\mathrm{U}_{0} \mathrm{D}$ needed 
to suspend the solids in the full-scale tank after dividing by 1.33, and the maximum $\mathrm{U}_{0} \mathrm{D}$ of each pump. The data show that two standard slurry pumps will not suspend the MST, two Quad Volute pumps are marginal, and two Submersible Mixer Pumps (SMPs) will suspend the MST. Three SMPs will suspend the MST, also. The required $\mathrm{U}_{0} \mathrm{D}$ with three SMPs is less than the maximum $\mathrm{U}_{0} \mathrm{D}$ of a Quad Volute pump, so three Quad Volute pumps will be able to suspend MST after settling overnight. After the required $\mathrm{U}_{0} \mathrm{D}$ is reduced by 1.33 to account for the reduced impact of the cooling coils at full-scale, two Quad Volute pumps would be able to suspend the solids in Tank $50 \mathrm{H}$. Two standard slurry pumps are still insufficient.

Table 2. Pump Parameters Needed to Suspend MST after Settling Overnight ${ }^{11}$

\begin{tabular}{lll} 
Pumps & 2 & 3 \\
\hline $\mathrm{U}_{0} \mathrm{D}_{\text {pilot-scale }}$ & $1.56-1.82 \mathrm{ft}^{2} / \mathrm{s}$ & $1.36 \mathrm{ft}^{2} / \mathrm{s}$ \\
$\mathrm{U}_{0} \mathrm{D}_{\text {full-scale }}$ & $22.1-25.7 \mathrm{ft}^{2} / \mathrm{s}$ & $19.2 \mathrm{ft}^{2} / \mathrm{s}$ \\
$\mathrm{U}_{0} \mathrm{D}_{\text {full-scale-coil effect }}$ & $16.6-19.3 \mathrm{ft}^{2} / \mathrm{s}$ & $14.4 \mathrm{ft}^{2} / \mathrm{s}$ \\
Standard Pump $\mathrm{U}_{0} \mathrm{D}_{\text {full-scale }}$ & $13.6 \mathrm{ft}^{2} / \mathrm{s}$ & $13.6 \mathrm{ft}^{2} / \mathrm{s}$ \\
Quad volute pump $\mathrm{U}_{0} \mathrm{D}_{\text {full-scale }}$ & $21.7 \mathrm{ft}^{2} / \mathrm{s}$ & $21.7 \mathrm{ft}^{2} / \mathrm{s}$ \\
SMP $\mathrm{U}_{0} \mathrm{D}_{\text {full-scale }}$ & $29.0 \mathrm{ft}^{2} / \mathrm{s}$ & $29.0 \mathrm{ft}^{2} / \mathrm{s}$
\end{tabular}

Table 3 shows the pump requirements to resuspend MST that has settled for four weeks at $45^{\circ} \mathrm{C}$. The results show two SMPs will not resuspend the MST, but three SMPs will resuspend it. Comparing the required pump $\mathrm{U}_{0} \mathrm{D}$ with the maximum $\mathrm{U}_{0} \mathrm{D}$ of a Quad Volute pump shows three Quad Volute Pumps are marginal. After accounting for the reduced impact of the cooling coils at full-scale, the data shows that two SMPs may be able to suspend the MST particles and three Quad volute pumps may be able to suspend the MST particles.

Table 3. Pump Parameters Needed to Resuspend MST after Settling for 4 Weeks at $45{ }^{\circ} \mathrm{C}^{11}$

\begin{tabular}{lll} 
Pumps & 2 & 3 \\
\hline Shear Strength & $105-118 \mathrm{~Pa}$ & $105-118 \mathrm{~Pa}$ \\
$\mathrm{U}_{0} \mathrm{D}_{\text {pilot-scale }}$ & $2.4 \mathrm{ft}^{2} / \mathrm{s}$ & $1.59 \mathrm{ft}^{2} / \mathrm{s}$ \\
$\mathrm{U}_{0} \mathrm{D}_{\text {full-scale }}$ & $33.7 \mathrm{ft}^{2} / \mathrm{s}$ & $22.4 \mathrm{ft}^{2} / \mathrm{s}$ \\
$\mathrm{U}_{0} \mathrm{D}_{\text {full-scale-coil effect }}$ & $25.3 \mathrm{ft}^{2} / \mathrm{s}$ & $16.8 \mathrm{ft}^{2} / \mathrm{s}$ \\
SMP U $\mathrm{U}_{0} \mathrm{D}_{\text {full-scale }}$ & $29.0 \mathrm{ft}^{2} / \mathrm{s}$ & $29.0 \mathrm{ft}^{2} / \mathrm{s}$
\end{tabular}

Table 4 shows the pump requirements to resuspend MST and Sludge slurries that have settled for four weeks at $45^{\circ} \mathrm{C}$. The results show three SMPs will suspend greater than $99 \%$ of the solid particles. Comparing the required pump $\mathrm{U}_{0} \mathrm{D}$ with the maximum $\mathrm{U}_{0} \mathrm{D}$ of a Quad Volute pump shows three Quad Volute Pumps have the power to resuspend more than 99\% of MST plus sludge slurries. If the required $\mathrm{U}_{0} \mathrm{D}$ is reduced by $33 \%$ to account for the reduced impact of the cooling coils at full-scale, three Quad Volute pumps may be able to suspend more than 99.9\% of the particles. In addition, three standard slurry produce $94 \%$ of the $\mathrm{U}_{0} \mathrm{D}$ needed to suspend $99.8 \%$ of the particles and may be marginal for suspending the solid particles in Tank $50 \mathrm{H}$. 
Table 4. Pump Parameters Needed to Resuspend MST and simulated Solids slurries after Settling for 4 Weeks at $45^{\circ} \mathrm{C}$

Feed

$\mathrm{U}_{0} \mathrm{D}_{\text {pilot-scale }}$

Pumps

Shear Strength

Amount resuspended (\%)

$\mathrm{U}_{0} \mathrm{D}_{\text {full-scale }}$

$\mathrm{U}_{0} \mathrm{D}_{\text {full-scale-coil effect }}$

$\operatorname{Max} \mathrm{U}_{0} \mathrm{D}_{\text {full-scale }}$

Percent of Max $\mathrm{U}_{0} \mathrm{D}_{\text {full-scale }}$
MST+CST+Sludge

$1.36 \mathrm{ft}^{2} / \mathrm{s}$

3

$104-109 \mathrm{~Pa}$

$99.8 \%$

$19.2 \mathrm{ft}^{2} / \mathrm{s}$

$14.4 \mathrm{ft}^{2} / \mathrm{s}$

$29.0 \mathrm{ft}^{2} / \mathrm{s}$

$66 \%$
MST+CST+Sludge

$1.69 \mathrm{ft}^{2} / \mathrm{s}$

3

104-109 Pa

$99.92 \%$

$23.8 \mathrm{ft}^{2} / \mathrm{s}$

$17.9 \mathrm{ft}^{2} / \mathrm{s}$

$29.0 \mathrm{ft}^{2} / \mathrm{s}$

$82 \%$

Rheology testing showed MST that settled for four weeks at $45^{\circ} \mathrm{C}$ had a shear strength of 105 $118 \mathrm{~Pa}$. MST plus CST plus sludge that settled for four weeks at $45^{\circ} \mathrm{C}$ had a shear strength of 104 - $109 \mathrm{~Pa}$. Samples of MST plus "high sludge" that settled for four weeks at $45^{\circ} \mathrm{C}$ had a measured shear strength of $74-95 \mathrm{~Pa}$. Since there is no path for MST to be transferred to Tank $50 \mathrm{H}$ and the MST plus "high sludge" properties are comparable to sludge properties, this material is believed to be more typical of the solids in Tank $50 \mathrm{H}$ than the MST plus CST plus sludge sample. The reduced shear strength would lead to a larger cleaning radius and a reduced $\mathrm{U}_{0} \mathrm{D}$ needed to solids suspension.

The SCIX test data does not support using solely standard slurry pumps to suspend and remove solid particles from Tank $50 \mathrm{H}$.

An alternative strategy is to use $1-2$ standard slurry pumps to move settled solids away from the telescoping transfer pump (TTP) in Tank $50 \mathrm{H}$, prevent the solids from settling near the TTP, and have the solids settle and accumulate in another region of the tank. The accumulated solids would need to be removed from the tank at a later time.

\subsection{REVIEW OF TANK 50H OPERATING EXPERIENCE}

The author reviewed the information collected on the mounds observed in Tank $50 \mathrm{H}$ in 2003, and used the information to assess whether $1-2$ standard slurry pumps could prevent solids from accumulating under the TTP. ${ }^{19}$ He used the following approaches for the assessment: the cleaning radius approach and the critical shear stress approach.

\subsubsection{Cleaning Radius Approach}

Engineering Calculation J-CLC-H-00793 determined the size and location of the mounds observed in Tank 50H in 2003. ${ }^{19}$ Standard slurry pumps were located in risers E1 and B2. One of the mounds was located under the TTP (riser B5). The distance from the pump in riser E1 to the mound was 30.7 feet. The distance from the pump in riser B2 to the mound was 33.5 feet. Based on this calculation, the cleaning radius of the standard slurry pump was 30.7 - 33.5 feet with the solids in Tank 50H. The distance from the pump in riser E1 to the TTP is 38.5 feet. To ensure concentrated solids are not drawn into the TTP feed, the author recommends a minimum target cleaning radius of $38.5+5=43.5$ feet. 
SRNL measured the shear strength of a sample of the solids and found the shear strength to be 400 - 460 Pa for an undisturbed sample. ${ }^{20}$ Previous SRNL work found the cleaning radius of a slurry pump to be inversely proportional to the square root of the slurry yield stress. ${ }^{21}$ Previous PNNL work found the cleaning radius to vary with slurry shear strength according to equation [2]

$$
\operatorname{ECR} \alpha \mathrm{D}_{\mathrm{j}} \mathrm{U}_{\mathrm{j}} \tau_{\mathrm{s}}^{-0.46}
$$

where $\tau_{\mathrm{s}}$ is the sludge shear strength. ${ }^{22}$ Assuming the shear strength of the solid mounds in Tank $50 \mathrm{H}$ was $400 \mathrm{~Pa}$, the cleaning radius was 30 feet, and the target cleaning radius is 43.5 feet (38.5 + 5 feet), the shear strength of any solid particles or mounds must be less than $180-190 \mathrm{~Pa}$ if they are to be adequately moved away from the TTP by $1-2$ standard slurry pumps.

Rheology data collected for the SCIX program with simulated sludge and MST (in a 660:1 ratio) that had settled for $1-13$ weeks at $30-45^{\circ} \mathrm{C}$ had a measured shear strength less than $100 \mathrm{~Pa}^{23}$ A sample of Sludge Batch 6 collected from a waste tank had a shear strength of $1.6 \mathrm{~Pa}{ }^{16}$

Analysis of samples collected from the solid mounds showed they contained high concentrations of oxalate and tetraphenylborate ${ }^{24}$, which would be atypical of the solids expected to be transferred to Tank $50 \mathrm{H}$ in the future. Tank $50 \mathrm{H}$ will continue to receive small amounts of oxalate from ETP, but it will not receive any additional tetraphenylborate. Previous rheology testing found $10 \mathrm{wt} \%$ tetraphenylborate slurries to have larger yield stress than sludge slurries with the same solids loading. ${ }^{25,26}$

If the shear strength of the solid material in Tank $50 \mathrm{H}$ is less than $180 \mathrm{~Pa}$, one standard slurry pump should be able to prevent large amounts of solids from settling under the TTP.

The author recommends the following approach for moving solid particles beyond the TTP. Mix the tank using the pump in riser E1. Rotate the pump for two hours. Following the two hour rotation, index the pump toward the TTP and mix for four hours. After the four hours of indexing, continue mixing for an additional two hours rotating the pump.

\subsubsection{Critical Shear Stress Approach}

Another approach to determine the pump requirements to produce a 43.5 foot cleaning radius is to look at the critical shear stress of the sludge. ${ }^{27}$ Previous work in the erosion of solid beds determined that no erosion occurred until a critical shear stress was applied to the bed. [A sludge with a smaller critical shear stress would be easier to mobilize than a sludge with a larger critical shear stress.]

The solid mounds observed in 2003 were 7 - 8 feet high. ${ }^{19}$ Most of this material has been removed from the tank. The solids that would be added to the tank in the future would be low concentrations of fine, slow settling solids. The height of any settled solids would be small (1 2 inches rather than $7-8$ feet). 
The solid particles would settle more compactly in a $7-8$ foot mound than in a $1-2$ inch layer. By settling more compactly, they would have a larger slurry density and a higher solids concentration. Previous work showed that beds with higher solids concentration or density had a larger critical shear stress. ${ }^{27}$ Other work showed the critical shear stress decreased with decreasing bed thickness. ${ }^{28}$ The largest source of feed to Tank $50 \mathrm{H}$ is the ARP/MCU, which has a $0.1 \mu \mathrm{m}$ filter to remove solid particles. The ETF evaporator bottoms will contain $\sim 1.5 \mathrm{wt} \%$ insoluble solids ${ }^{29}$, but this stream is a small fraction of the feed to Tank $50 \mathrm{H}$. The Super-Kukla stream will contain $1-2 \mathrm{~g} / \mathrm{L}$ of molybdenum ${ }^{30}$ that will form a precipitate when it is $\mathrm{pH}$ adjusted. This stream is a small fraction of the feed to Tank $50 \mathrm{H}$, and the molybdenum precipitate would have a similar size to SRS Tank Farm sludge. The evaporator overheads would not be expected to contain many solid particles. Since the solids that would be added to Tank $50 \mathrm{H}$ in the future would be fine ( $<5$ micron) and low concentration $(\sim 0.6 \mathrm{~g} / \mathrm{L})$, they should not form large mounds. Because of their small size, they would settle slowly and not pack. They should have a much lower critical shear stress than the solids mounds observed in 2003.

Work at the National Water Research Institute in Canada found that fine particles that settle have a lower critical shear stress (as much as 1/8) than beds deposited under shear. ${ }^{31}$ The solid particles that are added to Tank $50 \mathrm{H}$ in the future would settle slowly when the pumps were stopped. There would not be enough particles to form large mounds that are sheared by the pumps. Again, the critical shear stress of these solids would be less than the critical shear stress of the solid mounds observed in 2003.

Other research found that the top layer of a bed had a much lower critical shear stress than the bulk of the bed $(10-20 \mathrm{X}){ }^{32}$ The solid particles that would be transferred to Tank $50 \mathrm{H}$ in the future would be more characteristic of the top layer of a bed than the bulk of a bed several feet in depth. Again, the critical shear stress of these solids would be less than the critical shear stress of the solid mounds observed in 2003.

Because of these differences between the solid mounds observed in 2003 and the solid particles expected to be transferred to Tank $50 \mathrm{H}$ in the future, the cleaning radius of the standard slurry pumps would be larger in the future and should be sufficient to prevent large quantities of solid particles from settling under the TTP.

\subsection{DISCUSSION}

The analysis shows that three Quad Volute pumps should be able to suspend the solid particles in Tank $50 \mathrm{H}$. Three standard slurry pumps may not be able to suspend most of the solid particles in Tank $50 \mathrm{H}$. The data available suggests that two Quad volute pumps may not be able to suspend the solids in Tank $50 \mathrm{H}$. The data does not support the use of one or two standard pumps to suspend the sludge in Tank $50 \mathrm{H}$.

If SRS Liquid Waste wishes to prevent solid particles from accumulating under the TTP and can accept the accumulation of solid particles in other regions of the tank, one or two standard slurry pumps should be able to achieve a cleaning radius larger than 43.5 feet. This cleaning radius will prevent large amounts of solid particles from settling under the TTP. 
The author recommends the following approach for moving solid particles beyond the TTP. Mix the tank using the pump in riser E1. Rotate the pump for two hours. Following the two hour rotation, index the pump toward the TTP and mix for four hours. After the four hours of indexing, continue mixing for an additional two hours rotating the pump.

\subsection{CONCLUSIONS}

The conclusions from this analysis follow.

- The analysis shows that three Quad Volute pumps should be able to suspend the solid particles expected ( $\sim 6 \mathrm{~g} / \mathrm{L}$ insoluble solids, $\sim 5$ micron) in Tank $50 \mathrm{H}$.

- Three standard slurry pumps may not be able to suspend the solid particles in Tank 50H.

- The ability of two Quad Volute pumps to fully suspend all of the solid particles in Tank $50 \mathrm{H}$ is marginal.

- One standard slurry pump should be able to achieve a cleaning radius larger than 43.5 feet, which will prevent large amounts of solid particles from settling under the telescoping transfer pump (TTP). The report recommends a pump operating approach to maximize the achieved cleaning radius.

The author recommends the following approach for moving solid particles beyond the TTP. Mix the tank using the pump in riser E1. Rotate the pump for two hours. Following the two hour rotation, index the pump toward the TTP and mix for four hours. After the four hours of indexing, continue mixing for an additional two hours rotating the pump.

\subsection{REFERENCES}

${ }^{1}$ M. R. Poirier, T. B. Peters, E. A. Brass, S. J. Brown, M. W. Geeting, L. C. Johnson, C. J. Coleman, S. L. Crump, M. J. Barnes, and S. D. Fink, "Full-Scale Testing of a Caustic Side Solvent Extraction System to Remove Cesium from Savannah River Site Radioactive Waste”, Sep. Sci. Tech., vol. 43, No. 9-10, 2008, pp. 2797-2813.

${ }^{2}$ M. L. Crowder, "Results of Organic Carryover from the MCU Simulant Runs”, SRNLCST-2007-00070, June 28, 2007.

${ }^{3}$ K. A. Holloway, “Coalescer Decanter Test Report”, Wright Industries, Inc., N279426.1-024, Rev. 0, May 31, 2006.

${ }^{4}$ C. A. Nash, M. A. Norato, D. D. Walker, R. A. Pierce, R. A. Eubanks, J. D. Clark, W. M. Smith, S. L. Crump, D. Z. Nelson, S. D. Fink, T. B. Peters, C. G. May, D. T. Herman, H. L. Bolton, "Examination of Organic Carryover from 2-cm Contactors to Support the Modular CSSX Unit”, WSRC-TR-2005-00182, April 29, 2005.

${ }^{5}$ S. D. Fink, M. L. Restivo, T. B. Peters, M. D. Fowley, D. B. Burns, W. M. Smith, F. F. Fondeur, S. L. Crump, M. A. Naroto, D. T. Herman, and C. A. Nash, "Entrainment of Solvent in Aqueous Stream from CINC V-5 Contactor”, WSRC-TR-2005-00187, April 29, 2005.

${ }^{6}$ M. R. Poirier, F. F. Fondeur, D. P. Lambert, David T. Hobbs, and S. D. Fink, "Particle Size of Simulated SRS Sludge, Actual SRS Sludge, and Monosodium Titanate”, WSRCTR-2003-00221, May 20, 2003.

${ }^{7}$ WSRC-SA-2002-00007, Rev. 12. 
${ }^{8}$ John McCollough, “Assess Standard Pump Mixing Efficiency in Tank 50H”, HLETTR-2011-0011, May 5, 2011.

9 John McCullough, “Assess Standard Pump Mixing Efficiency in Tank 50H”, HLETTR-2011-0011, June 30, 2011.

${ }^{10}$ M. R. Poirier, "Assessment of the Ability of a Single Standard Slurry Pump to Mix Miscible and Immiscible Liquids in Tank 50H”, SRNL-STI-2011-00362, June 15, 2011

${ }^{11}$ M. R. Poirier, Z. H. Qureshi, M. L. Restivo, T. J. Steeper, M. R. Williams, "Investigating Suspension of MST Slurries in a Pilot-Scale Waste Tank", SRNL-STI2010-00793, January 24, 2011.

${ }^{12}$ M. J. Dalmaso, "Slurry Pump Configuration for Waste Removal”, WSRC-RP-93-456, March 17, 1993.

${ }^{13}$ C. L. Sharpe and D. B. Stefanko, “TNX/HLW Long Shaft Pumps 1995 - 2000”, WSRC-TR-2001-00313, June 2001.

${ }^{14}$ M. R. Poirier, "Mixing the Contents of the Salt Disposition Integration Project Blend Tanks”, SRNS-STI-2008-00480, February 18, 2009.

${ }^{15}$ S. Y. Lee and R. A. Dimenna, "Slurry Pump Mixing Effectiveness in Tank 50H”, WSRC-STI-2008-00151, February 2008.

${ }^{16}$ R. A. Leishear, M. D. Fowley, and M. R. Poirier., "SDI, Blend and Feed Blending Pump Design, Phase 1”, Savannah River National Laboratory, SRNL-STI-2010-00054, June 2010.

${ }^{17}$ M. R. Poirier and Z. Qureshi, "Scaling Jet Mixing of MST-Containing Solids in the Small Column Ion Exchange Process”, SRNL-STI-2010-00792.

${ }^{18}$ S. Y. Lee and B. W. Armstrong, "SDI CFD Modeling Analysis”, SRNL-STI-201100025 , April 2011.

${ }^{19}$ C. Banaszewski, “Tank 50 Solids Mound Volume Calculation”, J-CLC-H-00793, November 1, 2002.

${ }^{20}$ M. R. Poirier, “Tank 50H Solids Rheology”, SRT-LWP-2003-00023, February 13, 2003.

${ }^{21}$ B. V. Churnetski, “Effective Cleaning Radius Studies”, DPST-81-282, February 19, 1981.

${ }^{22}$ M. R. Powell, Y. Onishi, and R. Shekarriz, "Research on Jet Mixing of Settled Sludges in Nuclear Waste Tanks at Hanford and Other DOE Sites: A Historical Perspective”, PNNL-11686, September 1997.

${ }^{23}$ M. R. Poirier, C. E. Ferguson, D. C. Koopman, and T. B. Edwards, "Rheology of Settled Solids in Small Column Ion Exchange Process”, SRNL-STI-2011-00311, June 20, 2011.

${ }^{24}$ W. R. Wilmarth, C. J. Coleman, F. F. Fondeur, V. H. Dukes, M. P. Bussey, M. S. Blume, and A. V. Bowman, "Results of Sample Analysis of Tank 50H South Mound Solids”, WSRC-TR-2003-00068, January 20, 2003.

${ }^{25}$ D. D. Walker and J. P. Doherty, “The Effects of Gamma Irradiation on the Rheology of KTPB Slurries”, DPST-85-926, November 5, 1985.

${ }^{26}$ D. C. Koopman, A Comparison of Rheology Data for Radioactive and Simulant Savannah River Site Waste”, WSRC-TR-2004-00044, March 2004. 
${ }^{27}$ J. C. Winterwerp and W. G. M. Van Kesteren, "Introduction to the Physics of Cohesive Sediment in the Marine Environment", in Developments in Sedimentology, vol. 56, Amsterdam, Elsevier, 2004.

${ }^{28}$ M.-C. Aubert, M.-P. Elluard, and H. Barnier, "Shear Stress Induced Erosion of Filtration Cake Studied by a Flat Rotating Disk Method. Determination of the Critical Shear Stress of Erosion”, J. Membrane Sci., vol. 84, 1993, pp. 229-240.

${ }^{29}$ J. P. Bibler, S. B. Oblath, J. L. Siler, and J. R. Wiley, "Summary of ETF Process”, DPST-88-303, Rev. 1, March 17, 1988.

${ }^{30}$ R. A. Pierce, “Uranium-Molybdenum Dissolution Flowsheet Studies”, WSRC-STI2007-00103, Rev. 2, January 2009.

${ }^{31}$ Y. L. Lau and I. G. Droppo, "Influence of Antecedent Conditions on Critical Shear Stress of Bed Sediments”, Wat. Res. Vol. 34, No. 2, 2000, pp. 663-667.

${ }^{32}$ O. El Ganaoui, E. Schaaff, P. Boyer, M. Amielh, F. Anselmet, and C. Grenz, "The Deposition and Erosion of Cohesive Sediments Determined by a Multi-Class Model”, Estuarine, Coastal, and Shelf Science, vol. 60, 2004, pp. 457-475. 